are ambiguous, says Amedeo Santosuosso, a Milanese judge and a professor at the University of Pavia who specializes in science and law. "That has been the underlying problem in the Stamina debacle," he says. "In the case of the Stamina Foundation therapy, there is no suggestion that it might be efficacious, so in my opinion compassionate use is not legitimate."

Vannoni says that he developed the therapy after having successful stem-cell treatment for a virus-induced facial paralysis in 2004 in Russia. He invited a Russian and a Ukrainian scientist to Turin to develop the method and says that Stamina has since treated 80 or so patients including people with Parkinson's disease, $\mathrm{Alz}$ heimer's and muscle-wasting disorders. He has not published the outcomes or precise details of his therapy, which uses the mesenchymal stem cells from bone marrow that differentiate into bone, fat and connective tissue. In his protocol, the cells are extracted from patients, manipulated in the laboratory and then re-infused.

Vannoni acknowledges that he has not published outcomes but says that the method is far from alchemy. Each treatment uses five types of cell, he explains, with their claimed characteristics tuned to replace damaged tissue or to secrete molecules that could reduce inflammation, fight infection or promote blood-vessel growth. "Whatever the disease, one of the types of cell is going to have the right effect," he says.

When a 2007 European Union regulation required that stem-cell therapies follow the same safety and efficacy rules as pharmaceuticals,
Vannoni moved his lab to the republic of San Marino. "There, rules were not so strict," he says.

But his work had drawn the attention of a Turin prosecutor, Raffaele Guariniello, whose investigations concluded that Vannoni's operation could be "dangerous to public health". Vannoni says that Guariniello marshalled international pressure to stop him working in San Marino, so he moved to Trieste, where he says Guariniello again stopped his work.

From there, Vannoni moved to a public hospital in Brescia. Last May, a delegation including representatives of the Italian Medicines Agency (AIFA) and the ISS, the health ministry's national institute, visited the Brescia lab and reported chaotic conditions: ethics-committee approvals had been based on inadequate information, and there were no detailed protocols or patient follow-up, for example. The AIFA closed the lab, stating that the facilities could not be trusted to produce contamination-free preparations.

Patients and families turned to the legal system to allow treatments to continue as compassionate use; many of the courts concluded that it was a patient's right to receive treatment and that health services must offer it, and in some cases the Brescia lab once again supplied cells.

Some of the compelled treatments led to the only publication of clinical results so far. Clinicians at the Burlo Garafalo Children's Hospital in Trieste treated five babies with type I spinal muscular atrophy and published the results last October (M. Carrozzi et al. Neuromuscul.
Disord. 22, 1032-1034; 2012). They found that "the treatment did not change the course of the disease", says co-author Marco Carrozzi. Vannoni argues that the therapy failed because the clinicians did not use his exact cocktail of cells.

Setting himself against his own regulatory agencies, Balduzzi had earlier angered scientists when, on 7 March, he authorized continued therapy for a three-year-old child with the deadly disease metachromatic leukodystrophy - provided that the stem cells were created in

"The treatment
did not change
the course of the
disease."
a good manufacturing practice (GMP) facility. Thirteen academics, including Cattaneo and Santosuosso, published an open letter to Balduzzi warning him of the dangers (see go.nature.com/pb1wdl; in Italian).

That authorization was bad enough, says Paolo Bianco, a stem-cell scientist at the University of Rome who co-signed the letter. "Now the minister is allowing the non-GMP version and saying that an unauthorized, unpublished, unknown practice is a 'treatment."

Balduzzi's decree is likely to be his last legislative act in Italy's outgoing government, and scientists hope that his successor will respect the role of the AIFA and other science-based agencies. AIFA president Luca Pani declined to comment on the political decision but says that his agency is sticking to its statements on the safety and efficacy of the stem-cell preparations from Brescia. "Our ban holds," he says.

\title{
Drug-company data vaults to be opened
}

\section{European agency will publish firms' clinical-trial results.}

\section{BY DANIEL CRESSEY}

I nternational calls for the pharmaceutical industry to share the results of clinical trials have grown ever more intense amid revelations that high-profile companies have hidden crucial data on safety and efficacy. Now Europe is moving towards measures that would significantly increase disclosure of such data.

The European Medicines Agency (EMA) in London, which licenses drugs for use in the European Union, is developing a policy to publish some clinical-trial data submitted by companies. And next month, major players in the UK medical community will meet to discuss the practical problems of data openness.

The meeting is likely to take place on 19 April and could feature representatives from biomedical charity the Wellcome Trust, as well as the Academy of Medical Sciences, the Association of the British Pharmaceutical Industry and the Association of Medical Research Charities. It marks a move from discussion to action, says Nicola Perrin, head of policy at the Wellcome Trust in London. "We should all stop discussing whether [the issue is] important or not and start having practical discussions about how we move forward," she says.

The United States already requires that clinical trials used to secure drug approvals are listed in a public online registry. Other countries have rules that encourage registration. But some researchers and campaigners fear that key details are not getting into the public domain, making it difficult to assess a drug's safety and depriving researchers of data.

Critics note, for example, that in recent years the London-based drug company AstraZeneca has been mired in legal problems including accusations that it concealed data on the side effects of its antipsychotic drug Seroquel (quetiapine). And GlaxoSmithKline (GSK), also based in London, has paid out billions of dollars after pleading guilty to charges including misrepresenting the safety of its diabetes drug Avandia (rosiglitazone) and the effectiveness of its antidepressant Paxil (paroxetine) in children. The Cochrane Collaboration, an international group of medical experts, has called for Roche in Basel, Switzerland, to open up its data on the influenza drug Tamiflu (oseltamivir) so that the group can assess the drug's efficacy.

Drug companies are making concessions. GSK and Roche have agreed to share data with scientists whose requests are deemed legitimate. But critics say that Roche has not established a fully independent group to assess requests.

Last year, following pressure from campaigners, the EMA said that it would proactively publish certain data submitted by drug companies. The agency is consulting industry and academic researchers and funders on how this would work; it is likely to have a policy 
in place by 1 January 2014.

"Europe is now ahead of the United States in this area," says Lisa Bero, a pharmacologist at the University of California, San Francisco, who studies bias in scientific publication. "We're all waiting", she adds, to see what will unfold. "This is all very new."

Bero says that the move towards more transparency is a victory. But "there's going to be a lot more battles" over how information should be released, how detailed it should be, who should control its release and who should have access to data that might reveal identities of trial participants.

Campaigners such as All Trials, an international group launched in January to put pressure on governments and regulators, have demanded that public registration not be limited to trials used in drug-approval applications and should include full methods and results of past and current trials.

Many medical researchers would be satisfied if summary results were made public, ideally as peer-reviewed papers. But some want full release of the detailed clinical study reports that drug companies submit to regulatory agencies. Researchers who conduct meta-analyses by pooling data from multiple trials also want access to anonymized data on individual participants.

In 2010, the European Ombudsman ruled that detailed data should not be seen as commercially confidential. That helped to drive development of the EMA's policy, which will increase access to such information. But patient-level data are unlikely to be placed wholesale into the public domain, and companies, researchers, trial funders and patient groups disagree on who should decide which researchers can access them.

Groups also wrestle over who will enforce the rules. The UK Health Research Authority, which oversees standards and regulations in medical research, is assessing the practicalities of assigning the job to the same ethics committees that approve clinical trials.

Kay Dickersin, director of the Center for Clinical Trials at Johns Hopkins Bloomberg School of Public Health in Baltimore, Maryland, says that serious legal clout is needed when wrongdoing is exposed by transparency. If people have misrepresented studies, fines are not enough, she adds: for serious infringements, "someone has to go to jail".

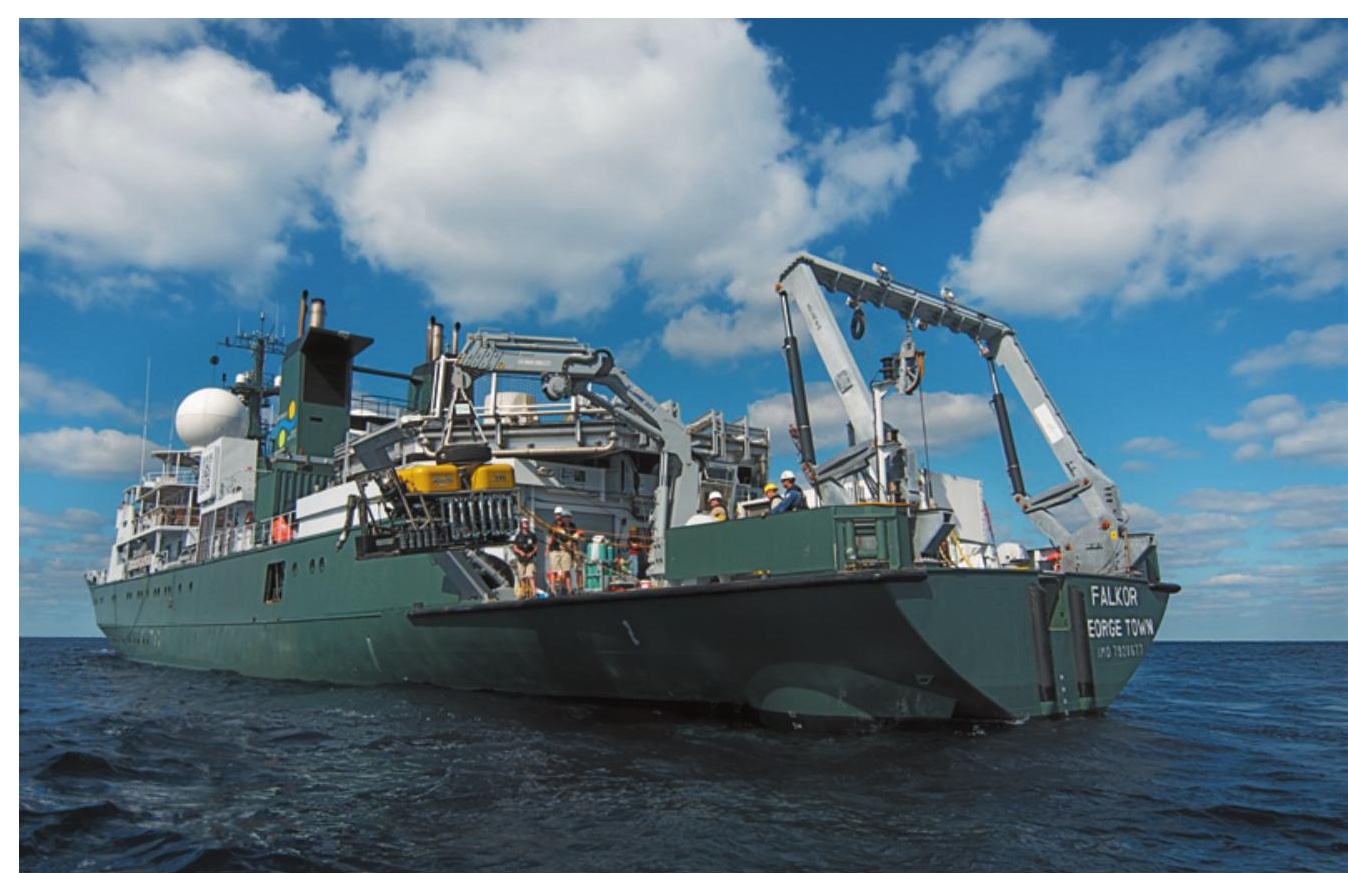

The R/V Falkor can deploy remotely operated submersibles.

\section{OCEANOGRAPHY}

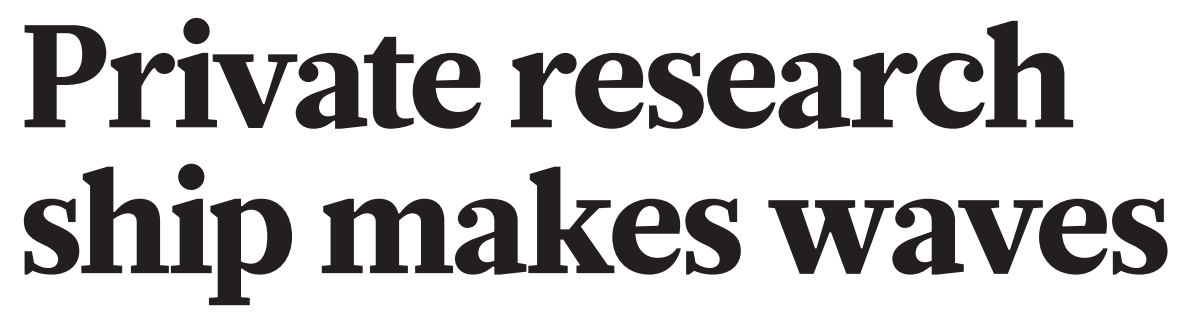

Falkor plots a fresh course for ocean studies with Google cash.

\section{BY ALEXANDRA WITZE}

$\mathrm{L}$ ife onboard the R/V Falkor is a far cry from the spartan existence endured by most academic oceanographers on research trips. The privately run research vessel features a sauna, a glassed-in lounge and a helicopter pad to be kept clear at all times for VIP guests.

All of which isn't too surprising, as two of the VIPs are the Falkor's benefactors: Google board chair Eric Schmidt and his wife Wendy. The 83-metre former fishery-protection vessel was retrofitted by the Schmidt Ocean Institute of Palo Alto, California, at a cost of
US\$60 million. Supporters say that it adds a new capability to US oceanography's fraying infrastructure: an ability to take on riskier projects more quickly than federal agencies can.

"Our hope is to accelerate the pace of research," says Wendy Schmidt. "It's not science as usual." The ship's first full-length science cruise ends on 29 March when it returns to port in St Petersburg, Florida, after a three-week trip.

For some oceanographers, the arrival of the Falkor - named after a lucky dragon in the film The NeverEnding Story - is a stroke of luck. The US research fleet is ageing and shrinking: down from 26 ships in the University-National Oceanographic Laboratory System in 1995 to

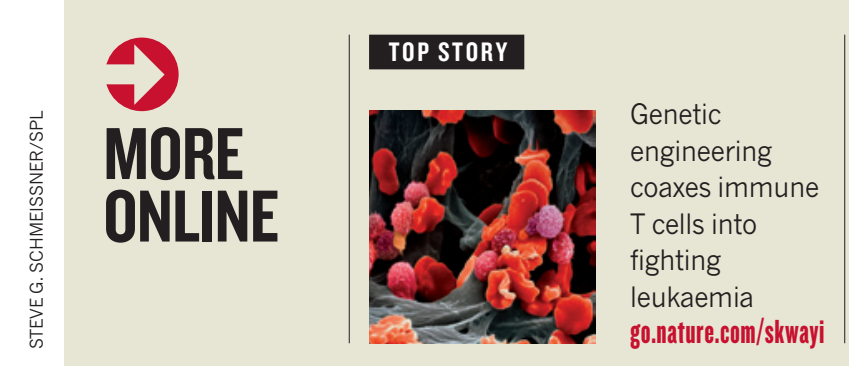

\section{MORE NEWS}

- US writers are less reserved than British ones go.nature.com/ugpp8a

- Lava eruptions led to dinosaur reign go.nature.com/nm6sxl

- Cosmic-ray fluctuations don't mean Voyager 1 'left the Solar System' go.nature.com/dzwmub

\section{VIDEO}

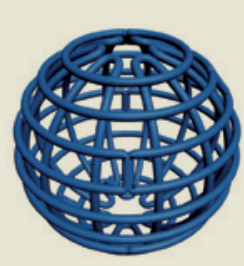

DNA origami uses crosslinks to enter into third dimension go.nature.com/ ziblu4 